requirement will shut out much useful material from candidature for entrance, and so cut down the supply of qualified teachers necessary for the growth in school population arising from the raising of the school-leaving age; the third, the implication that the work done by its own graduates is either badly done or not worth doing, a conclusion which I would fight with the gloves off.

(5) I now come to my last obstacle: headmaster and headmistress, alike, unenthusiastic and uninformed in the past.

If the teaching of cookery or nutrition in school is to take its rightful place in the curriculum, the urge must come from within the teaching profession as well as from without. The report of the Advisory Council on Secondary Education will be published almost certainly next week. We who know its convener are of opinion that it will be realistic; for my part I hope that it will be revolutionary in its proposals. The primary need of Scottish education is that it should break from the bonds which have tied it so long to the tails of university education. Its aim should be 'better living' in the widest sense, and in the discussions of the new curricula it should be the policy of all interested to see that education committees, directors of education, headmasters and headmistresses are left in no uncertain doubt as to their.obligations towards their girl pupils in the matter of domestic science teaching. I have assumed, you will notice, and I hope rightly, that the Scottish Education Department will not need pressure from lower levels, but will join actively in applying pressure from above. I have refrained from further reference to the university, as after hearing a professor of engineering state that he would as soon have Latin and Greek for a student's entrance qualification as French and physical science, I think it would take an atom bomb to move it from its complacency about the classical tradition.

My opinions have been stated frankly. They are my firm convictions, the result of my experience, and I am prepared to modify them as and when my further experience enables me to do so.

\title{
The Teaching of Cookery and Nutrition in Schools
}

\section{By C. M. KenNedy, Scottish Education Department, St Andrew's House, Edinburgh I}

Nutrition is one of the youngest of the sciences, but it is a highly important one. One has only to give a thought to the food situation of the world to-day to realize that nutrition, if not the very life of an individual, and indeed of nations, depends on the adequate production and effective distribution, the wise choice and suitable preparation of food for human consumption. Apart from life itself, good nutrition means good health, and good health is one of the main factors in promoting personal well-being, efficiency in work and play, and, in the long run, a sense of social worthiness.

The Scottish Education Department are well aware of the importance of right ideas about nutrition. In a memorandum issued in 1945 to education authorities on the subject of food education in relation to the domestic front, the Department advocated a wider extension of the means for instruction in nutrition and cooking to meet the 
needs of housewives, both young and old. They have also emphasized in a later communication to education authorities that, at the head of each local school-meals service, there should be, on the technical side, an officer whose qualifications include an adequate knowledge of dietetics. It is the duty of the Department's inspectors of schools, as occasion arises, to test and report on the nutritive value of meals served in schools, and inspectors of the school-meals service are specially appointed to supervise the arrangements for the feeding of schoolchildren throughout the country. Six months ago the Department encouraged education authorities to institute preapprenticeship courses for the catering and baking industries, laying down that nutrition should be among the subjects studied. It is the Department's view that, in the national interest, there is an increasing need for instruction in nutrition for pupils in the day schools and students in all continuation schools. The content of these courses and the manner of presentation should, of course, vary with the age and circumstances of the pupils and students concerned. Something has already been accomplished, especially with pupils in secondary schools. The pre-war practice was as follows:

(I) In general, cookery was taught first, some teaching on the general functions of food being included.

(2) After the principal methods of cookery had been demonstrated, food values were taught in more detail.

(3) Girls then received instruction on the foods useful for body-building, energy and heat. For girls under 5 years the differentiation of vitamins and salts was to some extent emphasized. Senior secondary girls were expected to learn the classification of nutrients into proteins, carbohydrates, and fats, more about vitamins and salts, and, in general, more advanced details of the functions of food.

The above applied only to girls receiving instruction in cookery, and was taught as part of the cookery lessons. In a few cases the proximate principles of food were taught as part of the science course for girls.

Advance in the teaching of nutrition on a large scale will, for a time at least, be difficult and slow. In dealing with the problem the following points, not always easy to separate from each other, must be considered: By whom is the subject to be taught? To whom is it to be taught? What is to be taught, and how is it to be taught?

\section{The teacher}

The lack of qualified teachers is one obstacle. More must be done in training teachers to impart up-to-date, accurate knowledge of nutrition in an interesting manner. In the meantime it is recognized that some attention is being given in the training colleges to the theoretical side of nutrition as part of the course of instruction in hygiene (school and personal). It is very necessary that school teachers should be so trained as to be able to give talks on nutrition. In the primary school the class teacher will deal merely with simple facts concerning nutrition and encourage a right attitude to food and good eating habits. Beyond that stage, apart from incidental reference by the class teacher or physical training teacher, the subject naturally falls to be taught in a more scientific way by the specialist teacher of cookery. 
The pupils

At the primary school stage both sexes should receive instruction and the subject should be treated in the course of hygiene or health lessons. Of secondary pupils, all girls taking cookery receive instruction in dietetics. Those who do not take cookery might have a few lessons in nutrition as part of their instruction in hygiene. PostLeaving Certificate intensive courses in cookery should include more study of nutrition than has hitherto been customary. As for boys, generally it is only those who wish to go to sea that take cookery, and for them instruction in dietetics would be specially valuable. Every effort should be made, however, to give all boys a short course in cookery and dietetics.

\section{The subject matter, and how it is to be taught}

At the primary school stage the teacher shuuld deal with the common foods familiar to the child, e.g. bread, sugar, milk, eggs, the potato, the carrot, the apple. For secondary school pupils the range can be extended, but it should not go beyond foods ordinarily available in this country. It is essential, particularly at the primary stage, that the handling of the subject should be simple, lucid, interesting, closely related to everyday life. It could be started with plasticine models, scrap-books, charts, and playing at housekeeping. Towards the end of the primary stage and at the beginning of the secondary stage, the historical approach will be found useful, e.g. the discovery of vitamins and the part they play in preventing certain diseases. The incidental study of food should seem natural to the children, so that they may absorb an elementary knowledge of the subject gradually and not become too food-conscious, the emphasis always being on the promotion of health in general. From the beginning of the secondary stage, where science, with its chemistry and biology, has come into the pupils' curriculum, instruction in dietetics might be linked up with science instruction, where elementary chemistry of food and physiology of digestion could be introduced, and, in alliance with these, dietary planning. At the highest stages those girls who take allied science* are specially well placed to study dietetics with understanding and success.

Finally, I may recall that whatever harm the war did, it gave a great stimulus to dietetics, theoretical and practical. In greater or less degree every household was constrained to take an interest in food and its nutritive value. The Government used schools and other agencies to foster an intelligent interest in this important subject; housewives received instruction on correct diet, on the importance and value of vegetables, and on how to provide in the most economical fashion a proper balance of foodstuffs in the daily régime. The dietitians of the Ministry of Food have issued excellent charts, which have been of inestimable value in the teaching of nutrition to school children and housewives alike. They have also given talks accompanied by visual aids, which have created great interest and have had a telling effect on the outlook of the ordinary citizen as regards the optimum nutritional state of the body. It is abundantly clear that citizens-to-be of both sexes cannot learn too soon and too well the relationship between food and human well-being in the home and among nations.

\footnotetext{
* See footnote on p. 94 .
} 
The approach to meal planning in the new 'home-making' scheme of work is more realistic and arouses greater interest than the old approach by way of the principles of cookery. We must not be too satisfied, however, with results attained so far; we must go on endeavouring to teach more about nutrition-and that more, better-and to continue to take advantage of research in the chemistry and physiological values of food.

\section{Nutrition in Adult Education}

\section{By R. C. GARRY, Department of Physiology, University College, Dundee, University of St Andrews}

Adult education in any form differs markedly from the education provided in childhood and in adolescence. In adult education compulsion cannot be applied, and, in Scotland at least, there are no examinations and no rewards in the form of certificates or diplomas. Success depends on the intrinsic attractiveness or usefulness of the topic under discussion. In theory such a system is ideal; the possession of new knowledge is sufficient reward for the labour involved in acquiring it. But all tutors of adult education classes know that the great majority of their pupils do hanker after some tangible evidence of the time they have spent studying in the class.

\section{Nutrition as a topic for adult education}

The importance and possibilities of nutrition as a suitable topic were not realized at first in the adult education movement as a whole. Initially there was a tendency for a strong sociological, even political, bias to influence the various organizations which busied themselves with adult education.

When local education authorities and universities began to play a part in adult education, however, emphasis was laid, as a corrective perhaps, on 'useless' knowledge, or on purely recreational studies. The confessedly utilitarian was regarded with suspicion, and classes dealing with human physiology and hygiene had to face opposition born of squeamishness. Until physiology is taught there can be no proper teaching of nutrition. The West of Scotland Joint Committee on Adult Education, with much misgiving, first sponsored a course of ten lecture-demonstrations on human physiology in 1927. Even in $1946-7$, only six of the 157 courses conducted by that Committee deal with human biology, and there is no course on nutrition as such.

On the other hand, we have had for a long time organizations wholly interested in food and in nutrition, many of them, unfortunately, anything but scientific. For the cold-blooded scientific study of nutrition is new; witness the genealogical tree at the beginning of Graham Lusk's The Science of Nutrition (Lusk, 1928). The realization that such knowledge must be passed on to our adult population is newer still.

The Food Education Society, founded in 1908 as The National Food Reform Association, was well before its time; still a power in the land, this society has many desirable reforms to its credit, but it may be doubted if these reforms were brought about by education of the people primarily concerned, namely, the citizens of this country. 